\title{
ПРИЗНАЧЕННЯ І ПРОЦЕСУАЛЬНИЙ СТАТУС СЛІДЧОГО СУДДІ У ДОСУДОВОМУ РОЗСЛЦДВАННІ
}

\begin{abstract}
ДАНЬШИН Максим Валерійович - доктор юридичних наук, професор, професор кафедри права Національної безпеки та правової роботи Військовоюридичного інституту Національного юридичного університету імені Ярослава Мудрого
\end{abstract}

ORCID https://orcid.org/0000-0003-2841-1891

КОСТЕНКО Марина Володимирівна - кандидат юридичних наук, доцент кафедри криміналістики Національного юридичного університету імені Ярослава Мудрого

ORCID https://orcid.org/0000-0002-1535-3912

АДАМОВ Федор Павлович - аспірант Харківського науково-дослідного інституту судових експертиз імені Заслуженого професора М. С. Бокаріуса Міністерства юстиції України

ORCID https://orcid.org/0000-0003-1844-1835

DOI 10.32782/LAW.UA.2021.2.8

\begin{abstract}
У статті розкриті призначення $i$ процесуальний статус слідчого судді у досудовому розслідуванні, а також висвітлені суттєві недоліки законодавчої регламентачиї судовоконтрольной діяльності у сфері забезпечення конститущійних прав $i$ свобод учасників кримінального провадження від будь-яких їх порушень з боку дізнавача, слідчого і прокурора та визначені шляхи усунення цих законодавчих прогалин. Авторами доведено, що визначена статтею 3 Конституцій України основоположна (загальнодержавна) функиія, пов'язана з визнанням людини найвищою соціальною иінністю, а утвердження $i$ забезпечення $\dddot{\imath}$ прав $i$ свобод головним обов'язком держави, є правозахисною (правозабезпечувальною) $i$ повинна неухильно виконуватися всіма органами державного апарату в усіх сферах державної діяльності. У стадій досудового розслідування кримінального процесу України ияю функцію виконують лише дізнавач, слідчий, прокурор і слідчий суддя у спещиббічній кримінальній процесуальній бормі. Перші три iз них реалізують ї на засадах законності 3 позиииї забезпечення прав і свобод усіх учасників кримінального провадження, виходячи із публічних (державних) інтересів. Слідчий же суддя реалізує означену функиію на засадах верховенства права, виходячи з позичиї, обумовленої
\end{abstract}

конститущійним статусом людини як найвищої сочіальної иінності $i$ недоторканності ї природних (невід'ємних) прав і свобод навіть з боку державних органів, до яких у стадій досудового розслідування відносяться дізнавач, слідчий $i$ прокурор, наділені повноваженнями на застосування примусових заходів кримінального прочесуального характеру.

Ключові слова: кримінальне провадження, досудове розслідування, судовий контроль у досудовому розслідуванні, слідчий суддя, права і свободи учасників кримінального провадження, правозахисна (правозабезпечувальна) діяльність, законодавець.

Постановка проблеми

3 прийняттям Верховною Радою України нового Кримінального процесуального кодексу (далі - КПК України) у нашій державі була започаткована нова змагальна модель (форма) кримінального провадження, а разом з нею виник судовий контроль у стадії досудового розслідування. Здійснення цього контролю законодавець поклав на нового владного суб’єкта стадії досудового розслідування - повноважного представника органів судової влади, який іменується слідчим суддею (п. 18 ч. 1 ст. 3 КПК України). Призначенням цього владного 


\section{Кримінальне право, кримінальний процес та криміналістика}

суб'єкта є здійснення у визначеному КПК України процесуальному порядку судового контролю за дотриманням прав, свобод та законних інтересів учасників кримінального провадження, залучених чи допущених до цього специфічного виду державно-правової діяльності у його стадії, яка носить назву досудового розслідування [1, с. 169225]. Основним же його завданням є недопущення порушень конституційних прав i свобод учасників процесу з боку владних суб'єктів досудового розслідування під час застосування ними широкого арсеналу примусових заходів процесуального характеру, передбачених нормами чинного КПК України.

Інакше кажучи, діяльність слідчого судді у стадії досудового розслідування полягає в тому, щоб цей повноважний представник судової влади, який виступає в ролі незалежного арбітра, не допустив під час проведення досудового розслідування кримінальних правопорушень, незаконних обмежень конституційних прав і свобод учасників кримінального провадження 3 боку дізнавача, слідчого і прокурора при виконанні ними процесуальних дій та прийнятті процесуальних рішень, пов'язаних 3 можливістю такого обмеження лише на законних підставах [2, с. 142]. Тож судовий контроль у досудовому розслідуванні є надійною гарантією забезпечення принципу верховенства права. Він спрямований не на вирішення кримінальної справи по суті, а лише на недопущення безпідставного порушення прав і свобод учасників процесу 3 боку держави в роботі дізнавача, слідчого і прокурора, уповноважених державою на застосування примусових заходів процесуального характеру [3, с. 157-164].

На відміну від інших владних суб'єктів досудового розслідування, які реалізують свої кримінальні процесуальні повноваження в односторонньому порядку, слідчий суддя реалізує судово-контрольну функцію лише в судових засіданнях, що йменуються судово-контрольними провадженнями i, як правило, проводяться з участю сторін обвинувачення і захисту в умовах змагальності. Правозахисна (правозабезпечувальна) діяльність слідчого судді реалізується лише за письмовими клопотаннями дізнавача, слідчого, прокурора і за скаргами учасників процесу, які діють у стадії досудового розслідування.

На відміну від дізнавача, слідчого, прокурора, слідчий суддя не має права починати досудове розслідування кримінальних правопорушень, виконувати будь-які слідчі (розшукові) дії чи негласні слідчі (розшукові) дії, ухвалювати будь-які процесуальні рішення обвинувального характеру, бо його судово-контрольна функція є суто правозахисною (правозабезпечувальною), зовсім не пов'язаною ні з безпосереднім розслідуванням кримінального правопорушення, ні з обвинуваченням особи, яка вчинила це правопорушення. Проте без використання унікальних повноважень слідчого судді кримінальна процесуальна діяльність дізнавача, слідчого і прокурора не може бути повноцінною [4, с. 128-133]. Судово-контрольна діяльність слідчого судді пронизує всі етапи досудового розслідування. Вона базується на положеннях Конституції України і КПК України, відзначається офіційним характером функціонування, компетенцією і правовими засобами (повноваження, форми, методи діяльності), визначеними законом, та специфікою кримінальних процесуальних рішень.

\section{Аналіз останніх досліджень і публікацій}

Питання про місце і роль слідчого судді у кримінальному процесуальному механізмі забезпечення прав учасників кримінального провадження має теоретичне і практичне значення, проте продовжує залишатися ще не достатньо дослідженим, бо є новим інститутом чинного КПК України 2012 року. У загальному порядку правозахисну (правозабезпечувальну) діяльність слідчого судді можна визначити як організовану за функціональним принципом і строго регламентовану кримінальним процесуальним законодавством його діяльність, спрямовану на недопущення незаконних обмежень прав учасників стадії досудового розслідування їі основними владними суб'єктами охорони обвинувачення - дізнавачем, слідчим і прокурором під час виконання пев- 
них слідчих (розшукових) дій, негласних слідчих (розшукових) дій та застосування заходів забезпечення кримінального провадження.

Мета статті - дослідити призначення і визначити процесуальний статус слідчого судді у досудовому розслідуванні.

\section{Результати дослідження}

Судово-контрольну діяльність у досудовому розслідуванні слідчий суддя реалізує у трьох формах: 1) ухвалення рішень (ухвал) про застосування заходів забезпечення кримінального провадження за письмовими клопотаннями дізнавача, слідчого та прокурора; 2) надання дозволу на проведення окремих слідчих (розшукових) дій та негласних слідчих (розшукових) дій за письмовими клопотаннями дізнавачів, слідчих та прокурорів; 3) розгляд письмових скарг учасників кримінального провадження на визначені законом рішення, дії чи бездіяльності дізнавача, слідчого, прокурора. Перші дві форми судового контролю носять превентивну спрямованість, а третя - невідкладну. Розгляд письмових клопотань дізнавачів, слідчих і прокурорів і письмових скарг учасників кримінального провадження слідчий суддя розглядає у судово-контрольних провадженнях. Якщо результати судово-контрольного провадження не дають підстав для задоволення клопотання дізнавача, слідчого, прокурора чи скарги учасника кримінального провадження, то слідчий суддя виносить ухвалу про відмову в задоволенні клопотання чи скарги.

Разом 3 тим, запровадивши до стадії досудового розслідування судово-контрольну форму забезпечення прав і свобод iï учасників, законодавець не надав поняттю «судовий контроль» термінологічного визначення ні в ст.3, ні в інших статтях КПК України 2012 року. Відсутність у законі розкриття всіх складових цього поняття (у тому числі й характеристики судових рішень), які приймаються під час здійснення судового контролю, а також відсутність офіційного тлумачення Конституційним Судом України конституцій- ного терміна «змотивоване рішення суду» щодо запобіжних заходів (ч. 2 ст. 29 Основного Закону) - дозвільне чи імперативне, змусили законодавця покласти на слідчого суддю обов'язок особисто застосовувати всі заходи забезпечення кримінального провадження, перетворивши його із незалежного арбітра у владного суб'єкта досудового розслідування, який бере безпосередню участь у прийнятті процесуальних рішень суто обвинувального характеру, чого в діяльності слідчого судді не повинно бути [5, с. 27-28]. На наше глибоке переконання, у змагальному кримінальному процесі слідчий суддя повинен надавати дізнавачу, слідчому і прокурору лише дозвіл на застосування заходів забезпечення кримінального провадження, а не особисто застосовувати ці заходи, стаючи в один ряд з обвинувачами, що розмиває задекларовану законом суттєву грань між функцією обвинувачення і функцією судового контролю.

Не можна надавати слідчому судді повноваження на забезпечення прав і свобод учасників досудового розслідування, в одних випадках застосовуючи дозвільний порядок вирішення клопотань дізнавача, слідчого і прокурора (при вирішенні питань про проведення окремих слідчих (розшукових) дій або негласних слідчих (розшукових) дій, пов'язаних 3 обмеженням прав і свобод учасників процесу), а в інших випадках - застосовуючи імперативний порядок вирішення клопотань дізнавача, слідчого і прокурора (при вирішенні питань про застосування заходів забезпечення кримінального провадження). Тут без офіційного тлумачення цих взаємовиключаючих норм процесуального закону Конституційним Судом України вже обійтися не можна. Для слідчого судді головним є лише проведення глибокої перевірки наявності чи відсутності законних і достатніх підстав для застосування дізнавачем, слідчим, прокурором певного заходу забезпечення кримінального провадження, щоби надати їм дозвіл або відмовити їм у наданні такого дозволу на його застосування. Визначати ж нагальну необхідність у застосуванні конкретного 


\section{Кримінальне право, кримінальний процес та криміналістика}

заходу забезпечення кримінального провадження i безпосередньо самому його застосовувати не повинно відноситися до компетенції слідчого судді.

Крім того, на відміну від кримінальних процесуальних повноважень дізнавача, слідчого, прокурора, чітко і повно визначених в окремих статтях чинного КПК України, повноваження слідчого судді у хаотичному порядку розкидані по різних статтях кодексу. Вони є ще й далеко не повними. Деякі з них потребують перегляду [6, с. 31-39]. Усунення цих суттєвих недоліків - одне із першочергових завдань вітчизняного законодавства. У законодавчому порядку також необхідно визначити, до якого напрямку діяльності слідчого судді відносяться такі його додаткові повноваження, як: встановлювати та поновлювати процесуальні строки; розглядати і вирішувати заяви про відводи дізнавача, слідчого, прокурора, захисника, представника, спеціаліста, перекладача, експерта, секретаря судового засідання; здійснювати допит свідка, потерпілого під час досудового розслідування у судово-контрольному засіданні; вирішувати питання про речові докази.

\section{Висновки}

Запровадивши до стадії досудового розслідування судово-контрольну форму забезпечення прав і свобод учасників досудового розслідування, законодавець України не врегулював кримінальний процесуальний порядок (процедуру) проведення судово-контрольних проваджень, чим суттєво ускладнив функціональну діяльність слідчого судді. Законодавцем України зовсім не визначені права і обов'язки учасників судово-контрольних проваджень, що суттєво ускладнює процесуальну діяльність слідчого судді, яка в обов'язковому порядку повинна регулюватися чіткими дозвільно-правовими нормами. $\mathrm{E}$ потреба i в доповненні чинного КПК України положенням про те, що про надходження до слідчого судді скарги від учасника досудового розслідування на незаконність прийнятого дізнавачем або слідчим процесуального рішення, чи незаконність його процесуальної дії чи бездіяльність, він (слідчий суддя) зобов'язаний повідомити наглядаючого прокурора, щоб той міг оперативно усунути допущене порушення закону своєю владою без втручання слідчого судді.

У чинному КПК України не визначено ще й вичерпного переліку форм взаємодії слідчого судді з наглядаючим прокурором, який поряд зі слідчим суддею також виконує правозахисну (правозабезпечувальну) функцію у кримінальному провадженні не $з$ позицій пріоритетності прав людини над державою (як діє слідчий суддя), а 3 позиції забезпечення публічних інтересів шляхом охорони інтересів особи, суспільства і держави [7, с. 51-52]. Ця проблема набуває важливого практичного значення, бо ці самостійні види кримінальної процесуальної діяльності доповнюють один одного в забезпеченні прав і свобод усіх учасників кримінального провадження. Відмінність цих процесуальних інститутів полягає лише в тому, що виконують вони свою правозахисну (провозабезпечувальну) діяльність різними кримінальними процесуальними способами. Законодавець України мусить значно розширити і зміцнити такі унікальні форми взаємодії прокурора зі слідчим суддею, коли розпочата прокурором правозахисна дія завершується слідчим суддею i, навпаки, коли правозахисна дія, розпочата слідчим суддею, завершується прокурором.

Досить непереконливим $є$ й використання законодавцем терміна «клопотання» у відносинах дізнавача, слідчого, прокурора зі слідчим суддею. Ці посадові особи є повноважними представниками рівноправних державних органів різних гілок влади. Тож неприпустимо перетворювати їх у прохачів при зверненні до слідчого судді. Тут більш доречним буде надання такому зверненню форми «подання», а не «клопотання», яке 6 характерним для визначення звернень приватних осіб до державних органів. Швидке усунення всіх означених нами законодавчих недосконалостей сприятиме значному покращенню результатів діяльності слідчих суддів у досудовому розслідуванні. 


\section{Мiтература}

1. Ларин А. М. Защита прав человека и гражданина в уголовном судопроизводстве. В кн. Общая теория прав человека / под ред. Е. А. Аукашова. М.: Норма. С. 169-225.

2. Марчак В. Я. Судовий контроль за додержанням прав людини згідно 3 кримінальним процесуальним законодавством України. Юридичний часопис Начіональної академії внутрішніх справ. 2013. №1 (5). C. 141-146.

3. Даньшин М. В., Кавун Ю. Д. Слідчий суддя у механізмі забезпечення і законних інтересів потерпілого. Вісник Харківського наиіонального університету іменіВ. Н. Каразіна. Серія «Право». 2016. Вип. 21. C. $157-164$.

4. Юрчишин В. М. Співвідношення прокурорського нагляду і судового контролю у досудовому розслідуванні за новим КПК України. Юридична Украйна. 2012. №11. С. 128-133.

5. Кальницкий В. Обоснованность производства следственных действий как предмет судебной оценки. Рос. юстиция. 2003. №2. С. 27-28.

6. Колоколов Н. А. Судебный контроль в стадии предварительного расследования: реальность и перспективы. Гос. и право. 1998. № 11. С. 31-39.

7. Кривобок В. В. Щодо співвідношення судового контролю та прокурорського нагляду за забезпеченням конституційних прав громадян у кримінальному судочинстві. Вісник Верховного Суду Украӥни. 2000 №5. C. 51-52.
The article reveals the appointment and procedural status of the investigating judge in the pre-trial investigation, as well as highlights the significant shortcomings of the legislation on judicial control in the field of constitutional rights and freedoms of participants in criminal proceedings from any violations by the coroner, investigator and prosecutor. addressing these legislative gaps. The authors proved that the fundamental (national) function defined by Article 3 of the Constitution of Ukraine, related to the recognition of man's highest social value, and the establishment and protection of his rights and freedoms - the main duty of the state, is human rights (law enforcement) and must be strictly bodies of the state apparatus in all spheres of state activity. At the stage of pre-trial investigation of the criminal process of Ukraine, this function is performed only by the coroner, investigator, prosecutor and investigating judge in a specific criminal procedural form. The first three of them implement it on the basis of legality from the standpoint of ensuring the rights and freedoms of all participants in criminal proceedings, based on public (state) interests. The investigating judge performs this function on the basis of the rule of law, based on the position determined by the constitutional status of man as the highest social value and inviolability of his natural (inalienable) rights and freedoms, even by state bodies, which in the pre-trial investigation include investigator and prosecutor, empowered to apply coercive measures of a criminal procedure.

Key words: criminal proceedings, pretrial investigation, judicial control in pre-trial investigation, investigating judge, rights and freedoms of participants in criminal proceedings, human rights (law enforcement) activities, legislator. 